\title{
The Urgency of Non-Precluded Measures Clause in Indonesian Bilateral Investment Treaty
}

\author{
Sefriani* \\ DOI: https://doi.org/10.22304/pjih.v6n2.a2
}

Submitted: April 26, 2019 | Accepted: August 15, 2019

\begin{abstract}
The legitimacy crisis of the Bilateral Investment Treaty (BIT) within the international community was caused by the increasing regulatory disputes before the Investor-State Dispute Settlement (ISDS) forum. It encourages Indonesia to discontinue several BITs, to review and to make new BIT models for Indonesia. This article aims to analyze the urgency of the non-precluding measures (NPM) clause in the new BIT Model of Indonesia to balance the interests of investors and the interests of Indonesia as the host state, considering that to date the existing BIT content is not balanced. The BIT provides so much protection to investors and, vice versa, weighty obligations to the host country. This study employed descriptive analytical method. The study concludes that the NPM Clause is very important in the new Indonesian BIT Model. At least, can be based on five arguments. First, the NPM clause will transfer risk from the country to foreign investors in situations of extraordinary threats. Second, the NPM clause will limit investor protection in certain situations. Third, the NPM clause will provide greater flexibility to Indonesia as the host to regulate its investment policy to achieve sustainable development to realize the people's welfare, labor rights, public health, safety environment, public morals, and order. Fourth, the NPM clause is important for self-recovery during international financial crisis. Fifth, lastly, the NPM clause will balance the protection of both investors and Indonesia as the host state.
\end{abstract}

Keywords: Bilateral Investment Treaty (BIT), investor, non-precluding measures.

\section{Urgensi Klausul Non-Precluded Measures dalam Bilateral Investment Treaty Indonesia}

\begin{abstract}
Abstrak
Krisis legitimasi terhadap Bilateral Investment Treaty (BIT) di masyarakat internasional yang disebabkan antara lain oleh semakin meningkatnya regulatory disputes' di forum Investor State Dispute Settlement (ISDS), mendorong Indonesia memberhentikan berlakunya beberapa BIT, meninjau ulang dan membuat model

PADJADJARAN Journal of Law Volume 6 Number 2 Year 2019 [ISSN 2460-1543] [e-ISSN 2442-9325]

\footnotetext{
Lecturer of International Law, the Faculty of Law, Universitas Islam Indonesia, S.H (Universitas Gadjah
} Mada),M.H. (Universitas Padjadjaran), Dr. (Universitas Gadjah Mada), sefriani@uii.ac.id.
\end{abstract}


BIT yang baru untuk Indonesia. Artikel ini bertujuan untuk menganalisis urgensi klausul non precluding measures (NPM) dalam BIT Indonesia yang baru untuk menyeimbangkan kepentingan investor dengan kepentingan Indonesia selaku tuan rumah (host state) mengingat selama ini kandungan BIT tidaklah imbang. BIT memberikan perlindungan yang begitu besar pada investor dan sebaliknya kewajiban yang begitu berat kepada negara tuan rumah. Metode analisis yang digunakan adalah deskriptif analitis. Hasil kajian yang dilakukan penulis menyimpulkan bahwa Klausula NPM sangat penting untuk dimasukkan dalam Model BIT Indonesia yang baru, berdasarkan 5 argumen yaitu bahwa: klausula NPM akan mengalihkan resiko dari negara ke investor asing Dalam situasi adanya ancaman yang luar biasa,; klausul NPM akan membatasi perlindungan investor dalam situasi-situasi tertentu; Klausul NPM akan memberikan fleksibilitas yang lebih besar kepada Indonesia selaku tuan rumah untuk mengatur kebijakan investasinya dalam rangka mencapai pembangunan yang berkelanjutan (sustainable development) untuk mewujudkan kesejahteraan masyarakatnya, melindungi hak-hak buruh, kesehatan masyarakat, keselamatan, lingkungan, moral publik atau ketertiban umum; Klausul NPM penting untuk pemulihan diri manakala mengalami krisis keuangan internasional; dan bahwa Klausul NPM akan menyeimbangkan antara perlindungan terhadap investor dengan perlindungan terhadap Indonesia sebagai host state.

Kata kunci: Bilateral Investment Treaty (BIT), investor, non precluding measures.

\section{A. Introduction}

Bilateral investment Treaty (BIT) is an agreement between two countries for mutual development, promotion, and protection in one of the countries territories covering operations of companies from the other country. ${ }^{1}$ Conceptually, BIT is based on the principle of reciprocity. In general practice, BIT is known as an international legal instrument. BIT's contents provide so much protection for foreign investors who invest in host country.

Based on BIT, a host state is committed to protect foreign investors and to provide compensation for actions that are detrimental to foreign investors. Currently, there is a legitimacy crisis of BIT and ISDS (Investor state dispute settlement) due to the number of regulatory disputes. ${ }^{2}$ The investor states examine some host government measures that are considered to violate BIT. The measures lead to chilling effects on the state's power to regulate. ${ }^{3}$

1 Rahmi Jened, Teori dan Kebijakan Investasi Langsung (Direct Investment), $1^{\text {st }}$ edition, Jakarta: Kencana, 2016, p. 361.

2 Vera Korzun, "The Right to Regulate In Investor-State Arbitration: Slicing And Dicing Regulatory Carve-Outs", Vanderbilt Journal of Transnational Law, Volume 50, 2018, p. 373.

$3 \quad$ lbid. 
The issuance of new rules that are considered burdening investors, as well as inactions like the failure to start an investigation into an allegedly fraudulent investment scheme can trigger regulatory disputes. ${ }^{4}$ In the case of Lone Pine Resources Inc. vs. The Government of Canada, Lone Pine Resources sued Canada because the Act to Limit Oil and Gas Activities issued by local Quebec Government revoked the exploration permit in St. Lawrence River, including a license belonging to Lone Pine Resources. ${ }^{5}$ Canada states that the Act is a legitimate act of the sovereign state in the public interest that applies without discrimination to all exploration permit holders. The purpose is to protect the St. Lawrence River. The law cannot be considered as arbitrary, unfair, or inequitable measure. ${ }^{6}$ The action of the Quebec Government is not an arbitrary takeover as held by foreign investors.

In 2011, the tobacco company Phillip Morris, due to the enactment of the Tobacco Plain Packaging Act 2011 (the Tobacco Act"), sued Australia. The Tobacco Act is believed to prohibit the plaintiff from using their intellectual property on the packaging of their cigarette products. The Tobacco Act requires the use of plain packages of cigarette products to protect and to improve public health by making aware of the danger of smoking, encouraging people to stop smoking, and reducing people's exposure to cigarette smoke. Phillip Morris argues that the Tobacco Act is a direct and indirect expropriation of investments without adequate compensation. Phillip Morris, based on the 2010 Arbitration Rules, submitted the lawsuit against Australia to UNCITRAL. ${ }^{7}$ In response, the Australian Government says that the obligation of plain package is not a discriminatory regulation since the purpose is to protect public health. ${ }^{8}$

Previously, at the end of 2001, Argentina experienced a very severe financial and economic crisis, deemed as the financial collapse of catastrophic proportions. In just one day, the Argentinian Peso lost $40 \%$ of its value. There were massive withdrawals of funds from banks. Revenue per person shrank from around US\$7,000 to only US\$3,500. Unemployment rate rose to reach $25 \%$. The economic crisis soon affected the political environment. In December 2001, a riot killed 30 civilians and led to the resignation of President Fernando de la Rua. The government was collapsed. At the end of 2002, more than half of Argentina's

\footnotetext{
Ibid, p. 380.

Jeongho, Nam, “Model BIT: An Ideal Prototype Or A Tool For Efficient Breach?”, Georgetown Journal of International Law, Volume 48, 2017, p. 1282.

Ibid.

7 Michael Nolan, "Challenge to the Credibility of the Investor state arbitration system", American University Business Law Review, Volume 5, Issue 1, 2015, p. 432.

8 Nikesh Patel, "An Emerging Trend in International Trade: A shift to safeguard against ISDS abuses and protect host state sovereignty", Minnesota Journal of International Law, Volume 26, 2017, p. 296.
} 
population lived below the poverty line. ${ }^{9}$ The economic crisis in Argentina is almost similar to the United States' Great Depression of the 1930s. On January 6, 2002, the Argentine Congress approved a "Public Emergency Law" to restore stability and public order. ${ }^{10}$ The Argentina's new government adopted a number of measures to stabilize the economy and restore political confidence. The efforts included the devaluation of Peso through termination of the currency board. The action pegged the value of the Peso to the US Dollar; 'pesification' of all financial obligations, freezing all bank accounts, etc. The series of actions were known collectively as Corralito. ${ }^{11}$

Although the steps offer a long-term prospect of restoring confidence and economic stability, they caused impacts that are detrimental to many economic actors in Argentina, including foreign investors. The foreign investors then sought legal protection under the BIT regime that Argentina used to make since 1980s and 1990s. ${ }^{12}$ The foreign investors filed no less than 43 claims to Argentina in front of ICSID with the value of the lawsuit reaching US\$8 billion. This amount is greater than the entire Argentine government financial reserves in 2002. Some speculation even claims that the total claim against Argentina could reach US\$80 billion. ${ }^{13}$

In Indonesia, the establishment of the Law Number 4 of 2009 on Mineral and Coal Mining (the Minerba Law) requires mining companies to divest shares of at least $51 \% .{ }^{14}$ The Law also requires companies to process raw mineral refining in Indonesia before smelters to provide added value to the export products. The Law also changes the form of contract of work into mining permit (IUP -ljin Usaha Pertambangan) or special mining permit (IUPK - Ijin Usaha Pertambangan Khusus) in addition to change tax ${ }^{15}$ and royalty rules. The clauses aim to make Indonesia's natural wealth for the welfare and prosperity of the Indonesian people since

9 William W. Burke-White and Andreas von Staden, Winter, "Investment Protection In Extraordinary Times: The Interpretation And Application Of Non-Precluded Measures Provisions In Bilateral Investment Treaties", Virginia Journal of International Law, Volume 48, Issue 2, 2008, p. 309.

10 Federico Godoy, "State of Necessity and Non-Precluded Measures-Implications of the Sempra and Enron Annulment Decisions", Arab, IBA Arab News, Issue 1, p. 167.

11 William W. Burke-White and Andreas von Staden, op.cit., p. 309.

12 Ibid, p. 310.

13 Ibid, p. 311.

14 The term divestasi in Indonesian law terminology is originally taken from the English term divestment, sometimes the term Indonesianisation is used interchangeably. According to Article 1 Number 8 of the Government Regulation Number 23 of 2010 on the implementation of mineral and coal mining business activities, stock divestment is the number of foreign shares that must be offered to Indonesian participants. See Salim. H.S., Hukum Divestasi di Indonesia, Jakarta: Erlangga, 2010, p. 102.

15 The amount of IUPK tax holder follows the applicable taxation rules, so the changes follow the relevant taxation rules in effect. The PT. Freeport wants the tax rate to be stable since the agreement is made unchanged until the contract period ends (naildown), as stipulated in the Contract of Work. See Arman Nefi, et.al., "Implikasi Keberlakuan Kontrak Karya Pt Freeport Indonesia Pasca Undang-Undang No 4 Tahun 2009 Tentang Pertambangan Mineral Dan Batubara", Jurnal Hukum dan Pembangunan, Volume 48, Issue 1, 2018, p.155; Maria Contesa, et.al., "Smelter: Inkonsistensi Kebijakan, Kendala dan Dampak di Indonesia", Responsive, Volume 1, Issue 1, 2018, p. 7. 
Article 33 of the 1945 Constitution Indonesia mandates it. At least two foreign companies, $\mathrm{PT}^{16}$ Newmont and PT Freeport Indonesia, threaten Indonesia to bring this matter to international arbitrary. Both companies feel that the Minerba Law is not in accordance with the contract of work that they had previously signed with the Indonesian government.

PT Freeport Indonesia signed the first contract of work in 1967 for 30 years period. They signed the second contract of work in 1991 and it will be expired in 2021. Investors generally hold to a clause called stabilization clause. Based on the clause, the mining concession agreement signed by the company and the Indonesian Government is based on the effective positive law and may not be changed arbitrarily by any one of the parties of the agreement. Any changes on the content of the contract must go through a negotiation process. This stabilization clause had caused various problems since the contract is valid for decades while Indonesia experiences legal development. Eventually, the agreement of the contract of work is considered no longer in line with Indonesian law and the concept of mining management for the prosperity of the people. ${ }^{17}$ The threat of a lawsuit to arbitration is one of the factors that make the government inconsistent in implementing the Law Number 4 of 2009. This is apparent from the continued revision of smelter obligations in the Minerba Law, which ultimately confuses mining entrepreneurs and smelter companies. ${ }^{18}$

The cases above have similarities in which state is sued or threatened to be arbitrated because the state issued a public policy to protect the interests of the host state people. This state policy is considered detrimental to investors and violates the principles of protection guaranteed by BIT. Generally, investors will adhere to the principles of pacta sunt servanda, stabilization clause in contract between investor and host state, as well as the doctrine of the sanctity of contract, which requires parties to respect and to carry out all obligations upon in contract. On the other hand, host state adheres to the sovereignty of its state and the right to make rules for the good of the people.

It is very interesting that the self-defense efforts carried out by Argentina that use the Non-Precluding Measures (NPM) clause in the BIT that they made with the country of origin of foreign investors. This clause can be found in the BIT between Argentina and The United States, Germany, and The Belgian-Luxembourg Economic Union (BLEU). ${ }^{19}$ The NPM clause limits the protection of investors, which, in exceptional circumstances, allows the state to take actions that are not

\footnotetext{
Stands for Perseroan Terbatas. It is a local term for Limited Liabilities Company.

Arman Nefi, et.al., op.cit., p. 146.

Maria Contesa, et.al., loc. cit.

William W. Burke-White and Andreas von Staden, op.cit., p. 311
} 
consistent with the agreement. The NPM clause allows the host state to conduct impairment of covered investment as long as the government acts based on the NPM clause. ${ }^{20}$

In the case of a lawsuit against Argentina at the ICSID forum, the Argentine lawyer, Procuración del Tesoro de la Nación, argues that, based on the NPM clause, the devastating economic crisis of 2001-2002 should free Argentina from the responsibility. ${ }^{21}$ Article XI of the BIT of the United States and Argentina says as follows. ${ }^{22}$

"This Treaty shall not preclude the application by either Party of measures necessary for the maintenance of public order, the fulfillment of its obligations with respect to the maintenance or restoration of international peace or security, or the protection of its own essential security interests"

The clause should be able to be used as a defense against the claim that Argentina violates investment treaty obligations. ${ }^{23}$

The NPM clause is very important because it gives state flexibility to protect its public interests in exceptional circumstances. It is able to free state from liability claims related to policy changes that are not in accordance with investment agreements when the policy is considered very important to protect the broad interests of people. Nevertheless, the NPM Clause needs to be formulated carefully to provide legal certainty and protection to investors based on the BIT to provide protection to foreign investors from arbitrary actions of host state.

Currently, Indonesia and other states such as India, South Africa, Canada, Australia, China, etc. are vigorously reviewing their investment agreements. According to the Investment Coordinating Board (BKPM-Badan Koordinasi Penanaman Modal), Indonesian BITs need to be reviewed for some reasons due to the increasing number of lawsuits and amount of compensation that uses BIT as a basis for a lawsuit, which foreign investors submit to Indonesia in front Investor State Dispute Settlement (ISDS) forum. ${ }^{24}$

During 2011-2016, the Indonesian government faced the increase of the number of lawsuits in the State Dispute Settlement (ISDS). ${ }^{25}$ During 1990-2009 (19

20 Ibid, p. 312.

21 Julie Kim, op.cit, p. 312.

22 Federico Godoy, "State of Necessity and Non-Precluded Measures - Implications of the Sempra and Enron Annulment Decisions", IBA Arab News, Issue 1, 2011, p. 167.

23 Javier Garcia Olmedo, "The Balance between NPM Clauses and Investors Protection under BITs: The Enron Annulment Decision”, IBA Arab News, Issue 1, 2011, p. 178.

24 Badan Koordinasi Penanaman Modal, "Review P4M Indonesia-Negara Mitra", this paper is presented in Invest Remarkable in Indonesia, Jakarta, May 2015, p. 3

25 Indonesia for Global Justice, "Catatan dari Sengketa Investasi \& Perdagangan Internasional", http://igj.or.id/wp-content/uploads/2017/01/Akhir-dari-sengketa-Perjanjian-Internasional.pdf, accessed on June 201. See also Sefriani, "Fair and equitable treatment standard in international investment agreements", Jurnal Yustisia, Voume. 7, Issue 1, 2018, p. 1. 
years) ${ }^{26}$, there are only nine cases but during 2011-2016, a span of five years, there are also five cases. They include Ravat Ali Rizvi, Churcill Mining and Planet Mining, Newmont Nusantara BV, Indian Metals and Ferro Alloys Ltd (IMFA), and Oleovest Pte, Ltd.

The following table describes the lawsuit filed by foreign investors in Indonesia and the value of the claims and the results. ${ }^{27}$

\section{Dispute Settlements in Investment Treaties}

\begin{tabular}{|c|c|c|c|c|c|}
\hline$\Leftrightarrow$ & $\cos a$ & 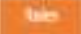 & 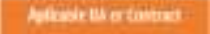 & dins & yous/ aning \\
\hline 190 & 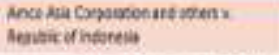 & $\mathrm{csc}$ & comas & $1500+2$ Lse & Decoet in Eveu di inetal \\
\hline 16 & 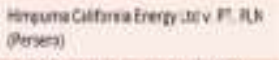 & SNCTRLi & Coms: & 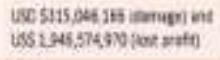 & Denits h twsu of meth \\
\hline $1+\mathrm{m}$ & 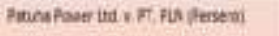 & INatraL & cominst & no & Decites in bevur it ineste \\
\hline $20 \infty$ & 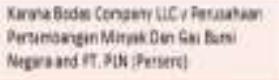 & UMCIRA & comses & 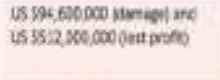 & Docted in weus of weater \\
\hline$z w$ & 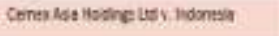 & 1000 & 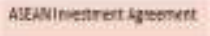 & 4000 rhus & Sotter \\
\hline $2 \times 0$ & 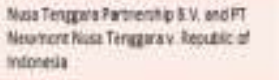 & $\cos 0$ & 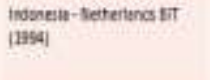 & no & Oacretival \\
\hline 200 & 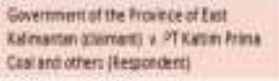 & ise & Consest & wor493nseist & Decoes in whar of metar \\
\hline vis & 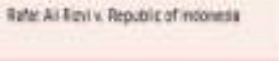 & 1090 & 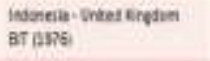 & $7500 \mathrm{ra} E \mathrm{ES}$ & dected in bveu o yser \\
\hline 211 & 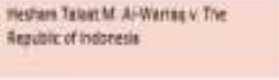 & WMathis & 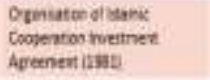 & $1340+2 \cos$ & 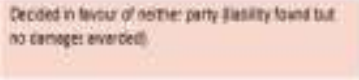 \\
\hline$z 12$ & 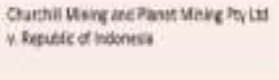 & cso & 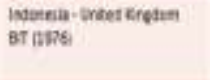 & $13: 5 \mathrm{Sma}$ แt & 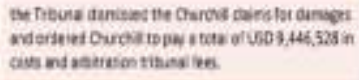 \\
\hline 2015 & 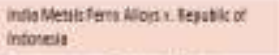 & UACTARS & 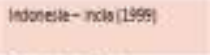 & sa11t minuse & Pendes \\
\hline xis & 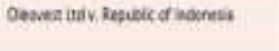 & ICSD & $\begin{array}{l}\text { AT homela-Sicases } \\
\text { |zosi }\end{array}$ & na & Anifre \\
\hline
\end{tabular}

Based on the data in the table, of the eight cases that have been decided by ISDS, Indonesia lost five cases and had to pay compensation that the amount is not small. Even in cases rejected by ISDS, court fees are often borne by both parties so that the costs burdens Indonesia. Not only against Indonesia, in general, there has been an increase of claims against host states in the ISDS. ${ }^{28}$ The material of the

26 Riyatno, "Investment dispute and international Arbitration", this paper is presented in BANI, 28 November 2017, p. 19.

27 Ibid.

28 James D. Fry and Odysseas G. Repousis, "Towards a new World For Investor -State Arbitration Through Transparency", New York University Journal of International Law and Politics, Vol. 48, No. 3, 2016, p. 801. 
lawsuit is state's policy to protect the basic rights of the people. It has given rise to a proposal that the Indonesian government should not include the ISDS clause in the new BIT. It is also proposed to withdraw from ICSID. ${ }^{29}$ In 2012, the government began to do a pre-review. Then, in 2013, the government tried to draft template/model of the Investment Protection Improvement Agreement (P4M Perjanjian Peningkatan Perlindungan Penanaman Modal) up to 2014. The 2014 P4M Draft is divided into fifteen important sections as follows. ${ }^{30}$

1. Preamble

2. Covered Investment

3. Definition of Investment

4. Investment License

5. Definition of Investor

6. Definition of Measure

7. Scope of Application

8. Treaty Claim and Contract Claim

9. Treatment of Investment on National Treatment, Most Favoured Nation Treatment and Standard of Treatment

10. Compliance with International Obligations

11. Compliance with Domestic Laws and Regulations

12. The Cause of Action under the Agreement

13. Investor-State Dispute Settlement

14. Governing Law in Dispute Settlement

15. Period in Force and Termination

Of the 15 important parts in the new Indonesian BIT draft, there is no NPM clause. In fact, the NPM clause is very important to give the state flexibility to use its sovereignty for the people protection. The BIT should not only protect investors but also host state. Therefore, the article analyzes the NPM clause in international investment law and the urgency of the NPM clause in the Indonesian BIT to balance investor interests with host state.

\section{B. Legitimizing the Use of the NPM Clause}

The existence of the NPM clause in the BIT is legitimate given the existence of the state right to regulate. State's authority to make rules in its territory is a fundamental embodiment of state sovereignty. The sovereignty is realized through the authority of state's legislative, administrative, and judicial institutions. State is free to adopt, to maintain, and to enforce the necessary measures for the progress and the achievement of public policy goals. Regulations are broadly understood to

\footnotetext{
29 Hikmahanto, J., “Indonesia Should Withdraw from the ICSID!", https://www.thejakartapost.com/news/2014/04/02/indonesia-should-withdraw-icsid.html, accessed on June 2019.

$30 \quad$ lbid, p. 8.
} 
include all acts of legislation, public administration, or even courts, which are the implementation of the regulatory or police power of the state. For example, state can commit itself to international investment agreement and carry out investor protection obligation. ${ }^{31}$

NPM clause is actually not only recognized in BIT. Although it does not use the term NPM, there are a number of similar international practices that can be used as a basis for the legitimacy of the existence of NPM clause in BIT. Before the introduction of NPM clause in the 1959 BIT between Germany and Pakistan, investor protection was granted through the Friendship, Commerce, and Navigation (FCN) agreement. FCN is based on the initial years of the Second World War. In fact, states were not ready to adopt the rules of international law to regulate their investment policies. Therefore, developed countries took the initiative to hold bilateral agreements with other countries in the field of investment. FCN does not use the term NPM. ${ }^{32}$ It used the term public order. ${ }^{33}$ Examples of public orders in FCN are religion or movement of foreigners. It is possible for a state to act contrary to its obligations in the FCN treaty whenever there is a reason for a public order. The example is contained in the United States' FCN treaty after World War II, which is applied in the 1984 International Court of Justice (ICJ) in the Nicaragua case and in The Oil Platforms Case through The USIran Treaty of Amity. ${ }^{34}$ However, in its development, FCN treaties are less effective in providing investor protection, especially to dispute resolution issues since FCN also covers non-commercial areas such as consular relations, immigration, religion, and individual rights. ${ }^{35}$

In addition to the FCN, the use of NPM clauses can also refer to the general exception provisions in Article XX of the GATT/WTO. General exception provisions provide the possibility for states to justify actions that are not in accordance with the obligations of the GATT/WTO. Article XX (b) of GATT provides exceptions in the form of important "trade-restrictive measures" to protect "human, animal, or plant life or health". Article XX (g) of GATT also provides exceptions for measures related to "the conservation of exhaustible natural resources if such measures are made effective in conjunction with restrictions on domestic production or consumption". The exception given by the GATT/WTO that applies the "least trade restrictive" approach aims to determine whether an action taken by state is a

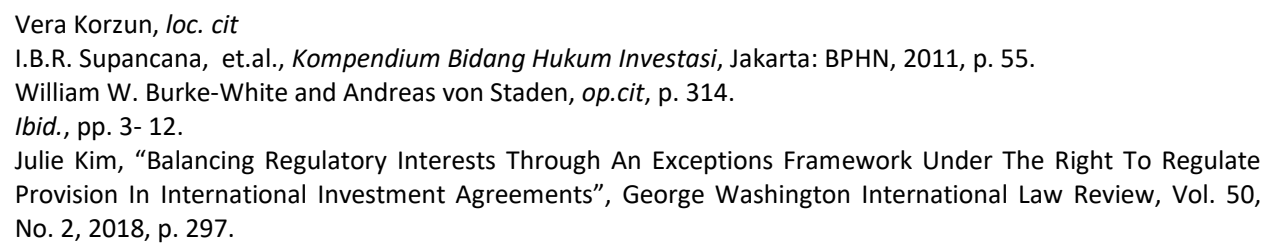


legitimate means of protecting health or environment. This exception can be used as a reference to be applied in an investment agreement. ${ }^{36}$

The legitimacy of the existence of NPM clauses in investment treaty can also refer to The Protocol to the Convention for the Protection of Human Rights and Fundamental Freedoms. This protocol stipulates that "[n]o one shall be deprived of his possessions except in the public interest and subject to the conditions provided for by law and by the general principles of international law."

In addition, the protocol also stipulates that human rights and fundamental freedom "shall not, however, in any way impair the right of a State to enforce such laws as it deems necessary to control the use of property in accordance with the general interest ${ }^{\prime \prime 37}$

The use of the NPM clause is also legitimate based on the use of state of necessity defense in customary international law. It is codified in the International Law Commission's Articles on State Responsibility on the Wrongful Act (ARSIWA). Article 25 of ARSIWA stipulates as follows.

"Necessity may not be invoked by a State as a ground for precluding the wrongfulness of an act not in conformity with an international obligation of that State unless the act:

(a) Is the only way for the State to safeguard an essential interest against a grave and imminent peril; and

(b) Does not seriously impair an essential interest of the State or States towards which the obligation exists, or of the international community as a whole. ${ }^{38}$

The use of NPM clause is recommended in the 2015 World Investment Report (WIR), related to the rights of host state to regulate public interests for achieving sustainable development. ${ }^{39}$ Based on UNCTAD's report, the results of a review of international investment agreements made in 2014 show that the majority of the International Investment Agreement (IIA) contain clause on the guarantee of protection of host state rights, namely the right to regulate for sustainable development objectives. Some contain general exception clauses for human protection, animal-or-plant life, or health, or the conservation of exhaustible natural resources. Another form is an international investment agreement that explicitly contains a clause that recognizes that "the parties should not relax health, safety, or environmental standards in order to attract investment". The UNCTAD also reports that there are twelve international investment agreements

36 Rahim Moloo and Justin Jacinto, “Environmental and Health Regulation: Assessing Liability Under Investment Treaties", Berkeley Journal of International Law, Volume 29, Issue 1, 2011, p. 7.

37 Ibid, p. 6.

38 Federico Godoy, "State of Necessity and Non-Precluded Measures - Implications of the Sempra and Enron Annulment Decisions", IBA Arab News, Issue 1, 2011, p. 168.

39 UNCTAD, World Investment Report 2015 reforming international Investment Governance, Geneva: United Nations Publication pp.107-108. 
that contain the importance of protections of health and safety, labor rights, the environment, or sustainable development. ${ }^{40}$ The existence of a clause that protects the right of state should not be interpreted as a reduction to the protection of investment. Most of the IIAs signed in 2014 still contain high investment protection standards, maintaining a balance between the interests of host state and investors. ${ }^{41}$

From the explanation above, there are different terms such as general exception, public order, public interest, state of necessity defense, etc. However, the goal is the same as the NPM clause in BIT. They are to exclude certain state actions from the demands of responsibility even though the actions are not in accordance with state's obligations. After the first BIT, the German-Pakistani BIT at the end of 1959, NPM clause can be found in almost every subsequent German's BITs, as well as the US' BITs. They are, among others, noted in BITs of Peru-Bolivia, Paraguay-Venezuela, Turkey-Qatar, Turkish-Moroccan, China-Singapore, ChinaNew Zealand, China-Sri Lanka, Switzerland-Chad, Mauritius-Uganda and the United Arab Emirates, and Uganda and Sudan-Eritrea. This list, although far from complete, has shown that NPM clause has significant importance in the international investment legal regime. Facts show that NPM Clause is also found in BITs of states that play major role in the international financial system, such as Germany, India, Belgium, Luxembourg, Canada, and the United States. They also appear sporadically in relations with many other states. Of the $2000 \mathrm{BITs}$ that are still effective, NPM clause appears in at least 200 of them. In its development, states also encourage the expansion of NPM provisions in certain agreements such as labor issues. ${ }^{42}$

\section{The Scope of the NPM Clause}

The classic understanding of BIT is that host state is committed not to harm foreign investors or, at the very least, will compensate if they do. In fact, NPM Clause carries out the functions of risk allocation, like transferring the cost of investment losses from the host state to investors in exceptional circumstances, as in the case of Argentina's financial crisis. NPM clause transfers risks to investor, and state is not be responsible for actions taken, which in normal conditions are in fact a violation of BIT. The prevalence of NPM clauses in BIT has significant implications for international investment regime in general. On one hand, BIT is recognized as a legitimate investor protection instrument and has a very strong position in cross-border investment relations. However, on the other hand, NPM

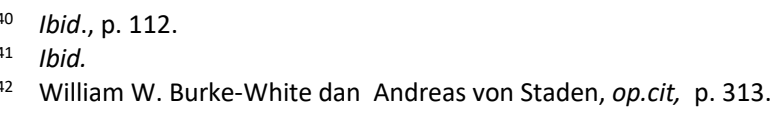


clause makes such protection in exceptional situations or crises invalid. ${ }^{43}$ The NPM clause has fundamentally limited legal regime that protects foreign investors. ${ }^{44}$

Indeed, NPM clause has legitimacy. However, the scope must be limited to provide legal certainty and to protect investors' interests. The following are examples of the scope of the NPM clause found in BITs. The first example is the NPM clause in the German-Pakistani BIT, which stipulates that measures taken for reasons of security and public order, public health, or morality will not be considered as discrimination, either it is based on non-discriminatory treatment of the national standard or the most favored nations. ${ }^{45}$ The second example is the NPM clause in the 1980s BIT of US-Panama as follows.

"[t]his treaty shall not preclude the application by either Party of any and all measures necessary for the maintenance of public order, the fulfillment of its obligations with respect to the maintenance or restoration of international peace and security, or the protection of its own essential security interests.

In its development, the NPM clause in the BIT of the US has experienced several modifications. In the 1990s and 2004, the BIT includes the following clauses respectively.

"a party was not precluded from taking any measures that "it considers necessary" for the protection of the stated permissible objectives.

"Nothing in this Treaty shall be construed: to preclude a Party from applying measures that it considers necessary for the fulfillment of its obligations with respect to the maintenance or restoration of international peace or security, or the protection of its own essential security interest." 46

The third example is the NPM clause in the Belgium-Luxembourg Economic Union (BLEU). ${ }^{47}$

"Except for measures required to maintain public order, such investments shall enjoy continuous protection and security, i.e. excluding any unjustified or discriminatory measure which could hinder, either in law or in practice, the management, maintenance, use, possession or liquidation thereof."

The fourth is the NPM clause listed in Article 11 of the Indian-English BIT as follows.

\footnotetext{
Ibid., p. 313.

Ibid., p. 314.

Ibid.

Ibid.

Ibid.
} 
"Notwithstanding paragraph (1) of this Article nothing in this Agreement precludes the host Contracting Party from taking action for the protection of its essential security interests or in circumstances of extreme emergency in accordance with its laws normally and reasonably applied on a non-discriminatory basis.

Some NPM clauses in other Indian BITs add that ${ }^{48}$ "reserve the right of each contracting party to take measures necessary for the prevention of diseases and pests in animals or plants".

The fifth example is the NPM clause in Article 10 of the 2004 Canadian BIT model, which refers to Chapter 11 of the North American Free Trade Agreement (NAFTA) as a guide. ${ }^{49}$

"measures necessary "(a) to protect human, animal or plant life or health; (b) to ensure compliance with laws and regulations that are not inconsistent with the provisions of this Agreement; or (c) for the conservation of living and non-living exhaustible natural resources".

Afterwards, Canada also includes measures necessary to preserve "integrity and stability of a Party's financial system, measures related to national and international security concerns, and measures adopted by a Party in conformity with a decision."

The scope of NPM clauses in various BITs includes the following aspects. ${ }^{50}$

1. Security. Variations of the phrases are public security, essential security interests, national security, internal or external national security; state security as well as extreme emergencies, which will cover security and other emergencies with certain gravity.

2. International Peace and Security.

3. Public Order. Even though it is difficult to define because public order of a state has different standards from others, some BITs expand the concept of public order as "state law". For example, the BIT between China and BLEU adds defense of state law to the maintenance of public order as an allowed purpose. Likewise, the agreement between the Russian Federation and Germany states "actions taken in the interests of law and order will not be considered discriminatory in the context of investment treatment".

\footnotetext{
48 See Article 12 of the Agreement for the Promotion and Protection of Investments between India and Netherlands, $6^{\text {th }}$ November 1995, http://www.iisd.org/pdf/2006/investment india netherlands.pdf.

49 See Article 10 of Canadian Model Foreign Investment Protection and Promotion Agreement, 2004, http://www.dfait-maeci.gc.ca/tna-nac/documents/2004-FIPA-model-en.pdf.

50 William W. Burke-White and Andreas von Staden, op.cit., pp. 332-335.
} 
4. Public Health. Canada's BIT allows measures needed to protect human, animal, or plant life or health. This scope covers the prevention of diseases and pests of animals and plants.

5. Public Morality. The scopes also include extreme emergencies, national interests ${ }^{51}$, conservation of living or non-living exhaustible natural resources if such measures are made effective in conjunction with restrictions on domestic production or consumption, reasonable measures for prudential reasons, ensuring the integrity and stability of a Contracting Party's financial system, terrorist threats, and financial crises.

In most cases, NPM clause liberates state from international responsibility, obligations to investors, and any obligations to pay compensation to investors. NPM clause is generally articulated as an exception to the BIT's substantive provisions and not merely as a justification or a reason for violations. NPM clause is made an exception through the use of the phrase "shall not preclude the applicability of measures" or "shall not apply to".

\section{The Differences of NPM Clause and Customary International Law}

In the case of lawsuit against Argentina, the ICSID Tribunal is inconsistent. They used different approaches in interpreting the nexus requirements (the term "necessary for") against the NPM clause in Article XI of the BIT of US-Argentina. In the case of CMS Gas Transmission Company vs. Argentine Republic (CMS), 23 Enron v. Argentine Republic (Enron), 24 and Sempra v. Argentine * 511 Republic (Sempra), the tribunal applies the necessity defense requirements in international customary law to interpret Article XI of the US-Argentina BIT and rejects Argentina's arguments based on the NPM clause. The tribunal punishes Argentina to be responsible to foreign investors. The tribunal in the case of the LG\&E v. Argentine Republic (LG\&E) 27 and Continental Casualty v. Argentine Republic (Continental Casualty) examined the NPM clause independently of the element of necessity in international customary law. The tribunal accepted the argument and exempted Argentina from liability claims against foreign investors. Although finally the verdict of the first group's tribunal was canceled because it was considered improperly combining the NPM clause with the necessity of defense in customary law, this has made a heated debate among academics. ${ }^{52}$

Customary international law codified in ARSIWA gives states some flexibility in exceptional situations. Some extraordinary conditions that can exclude state from accountability demands include force majeure, distress, and necessity. The conditions can relieve and even free state from the demands of international

51 The China-Sri Lanka BIT affirms, inter alia, the right of a Party to impose restrictions or restrictions of any kind or take any other measures directed at protecting its national interests. This formulation is very broad, potentially leading to unlimited deviations of BIT.

52 Ibid, p. 512. 
liability. Force majeure can be applied when there are "acts of God" outside a state's control intervene and make it impossible for the state to fulfill its legal obligations. Distress occurs when a state has no other way to safeguard a life in its care than to violate a legal rule. Necessity is applied when a state has no other means available to safeguard an essential interest and can do so without harming the essential interest of another state.

The provisions of NPM are different from what is stipulated in the ARSIWA regarding the substance, justification theory, source of legal authority, and the scope of application. In terms of substance, the NPM clause is relatively narrower. NPM clause is used to free parties from violations of obligations originating from investment agreements. Efforts to free from the demands of accountability of other parties in ARSIWA stem from violations of international law in general, not only violations of international treaties. The ARSIWA's background is that a state that violates an agreement can free the state from international legal responsibility. Instead, the NPM Clause removes certain types of actions taken by the state from BIT protection. ${ }^{53}$

Based on justification theory, the state's measures are justified because they are related to certain state's objectives such as public policy for sustainable development. Conversely, exceptions in the ARSIWA are justifications due to overriding systemic policy goals, such as the fact that actors should not jeopardized life or a state imperil its essential interests. ${ }^{54}$ Based on the source of its legal authority, NPM clause has a source of study authority or, as for ARSIIWA, its authority is from customary international law. NPM clause is lex specialis. There are differences based on the scope of application. The ARSIWA applies to all states but NPM only applies to parties to the BIT. The scope of the NPM clause depends on the agreement of the parties in the BIT. Therefore, there can be various kinds of NPM clause. The exceptions to ARSIWA are based on customary law.

In the case of Argentina, several ICSID tribunals have merged NPM clauses on defense grounds in customary law (ARSIWA), perhaps because they are accustomed to the term necessity in ARSIWA, where the state can free itself from being held accountable for its measures to "safeguard an essential interest against a grave and imminent peril..$^{55}$ Combining and equating customary law with agreements is inappropriate since it would violate the principle of effectiveness in

\footnotetext{
William W. Burke-White and Andreas von Staden, op.cit, p. 321.

Ibid.

55 "Necessity may not be invoked by a State as a ground for precluding the wrongfulness of an act not in conformity with an international obligation of that State unless the act: (a) Is the only way for the State to safeguard an essential interest against a grave and imminent peril; and (b) Does not seriously impair an essential interest of the State or States towards which the obligation exists, or of the international community as a whole". See Article 25 of Responsibility of States for Internationally Wrongful Acts.
} 
the interpretation of the agreement, as stated by the WTO appellate body panel in the US Gasoline case. ${ }^{56}$

"[o]ne of the corollaries of the "general rule of interpretation" in the Vienna Convention is that interpretation must give meaning and effect to all the terms of a treaty. An interpreter is not free to adopt a reading that would result in reducing whole clauses or paragraphs of a treaty to redundancy or inutility."

Thus, equating and combining the NPM clause with the customary defense of necessity will make the clause meaningless because the customary defense of necessity will be available to the country without seeing the existence of NPM Clause in BIT. To fulfill the principle of effectiveness in interpreting treaties, NPM clause must be read as a different set of rules made by state in treaty relations, regardless of the necessity of defense in customary international law. ${ }^{57}$

Treaties and customs are separate sources of international law and each is an independent legal regime. The ICJ in the Nicaragua case distinguishes these two sources of law even though their contents are identical and even though states are bound to the two sources of law. The two sources of law remain separate. ${ }^{58}$ Because of including NPM clause in the BIT, host state has created an agreementbased legal mechanism to allocate risk between them and investors in exceptional situations, which differ from, but coexist with, the defense available in customary international law. The only condition in which treaty rules can be considered to replace international customary law is if the treaty specifically shows that it supersedes international customary law or if the terms of the treaty and international customary law conflict with each other and cannot coexist. ${ }^{59}$

\section{E. The Urgency of NPM clause in Indonesian BIT}

Currently, Indonesian BIT is still more in favor of foreign investors. Almost all the BIT Articles contain protection of investors and the obligations of the host to realize the protections. Therefore, there are several arguments to justify the urgency of the NPM clause in the Indonesian BIT.

Firstly, in a situation of extraordinary threat, the NPM clause may transfer risk from the state to foreign investors. Customary international law only provides limited protection to investors. Instead, the BIT is to provide investors with greater security guarantees for their investments by ensuring compensation and providing a forum where investors can submit claims against the state. ${ }^{60}$ However, the existence of the clause is acceptable and is considered important in many BITs. The

\footnotetext{
William W. Burke-White and Andreas von Staden, op.cit., p. 323.

Ibid, p. 324.

Ibid, p. 323.

Julie Kim, Ibid.

William W. Burke-White and Andreas von Staden, op.cit., p. 383.
} 
NPM clause in the BIT can divert the costs of state measures that objectively meet the requirements and have the potential to harm investors. In short, the NPM clause relocates risk to investors, giving the state a lot of freedom to measure in responding extraordinary threats.

Based on the idea, the scope of the NPM clause agreed by the host state and investors will affect the interpretation of the arbitration to what extent the clause transfers risk from the state to the investor. The broader scope of the NPM clause is interpreted; and the more arbitration tribunals are subject to state demand, the more risk goes to investors. Accordingly, the Interpretation of the NPM clause will regulate the highest allocation of risk shifts between the host state and investors with respect to the measures of the state in response to exceptional circumstances. Of course, the host state cannot ask for the widest possible scope and interpretation of the NPM clause that will harm investors, especially if investment in the region is not attractive because this will reduce the flow of investment into the state. Investors will choose other states that are considered safer for their investment. ${ }^{61}$

Today, many states experience extraordinary, crucial, and unanticipated threats, such as terrorism, the collapse of currency values or financial crises, public health emergencies, and natural disasters. They can force states to take measures to respond to their interests so that the existence of NPM clauses with this risk allocation tends to become increasingly important. ${ }^{62}$

Secondly, the NPM clause will limit investor protection in certain situations that are very important for Indonesia as the host state because the NPM clause allows the host state to take actions that are not consistent with its obligations, which aims to maintain public order, national security, and others essential security interests. According to Vandeveld, an NPM is generally included in a BIT and later invoked because "some public policy concerns of the state are deemed sufficiently compelling that they are justified state interference with market-based allocations of capital". ${ }^{63}$ Thus, the existence of an NPM clause is important for the host state because it can "cut off all investor remedies under the BIT". ${ }^{64}$

Thirdly, the NPM clause will provide greater flexibility to Indonesia as the host to regulate its investment policies in order to achieve sustainable development to realize the welfare of people, protect labor rights, public health, safety, the

61 Ibid, pp. 401-403.

62 G. John Ikenberry and Anne-Marie Slaughter, "Forging a World of Liberty Under Law: U.S. National Security in the 21st Century", http://www.princeton.edu/ppns/report/FinalReport.pdf, accessed on June 2019.

63 Charity L. Goodman, "Uncharted Waters: Financial Crisis And Enforcement of ICSID Awards In Argentina", University of Pennsylvania Journal of International Law, Volume 28, Issue 2, 2007, pp. 475-476.

64 Ibid., p. 476. 
environment, public morals, or public order. ${ }^{65}$ BIT is usually an umbrella agreement for many concession contracts between the host state and foreign investors, which is generally effective for a long period of time ${ }^{66}$, during which time it is possible to change urgent needs or extraordinary threats faced by the host state. The existence of an NPM clause will help the host state realize the flexibility of protecting its national interests.

Fourthly, the existence and application of the NPM clause is important for Indonesia as the host state for the purpose of recovery after an international financial crisis and for the development of a bankruptcy mechanism involving the host state. The state can choose to draft an NPM clause that explicitly includes a response to the economic crisis, which is one of the situations of extraordinary threats permitted. The arbitration court can interpret it as "essential security" including the threat of economic collapse. In such cases, states can be freed from the obligations they should face under the BIT. Thus, the existence of NPM is very important to facilitate post-crisis recovery.

Fifthly, the existence of the NPM clause will balance the protection of investors with the protection of Indonesia as the host state. This is because almost all articles in the Indonesian BIT cover only protection for investors. The LG\&E Tribunal of the Argentina v. USA case recognizes that the BIT requires a balance of interests between investor protection and state freedom to carry out a policy or action. For the LG\&E Tribunal, the NPM clause is an explicit textual instrument to shift the costs of state action in exceptional circumstances from states to investors. $^{67}$

\section{F. Conclusion}

NPM clause is not a new matter in international law. The clause has legitimacy in international law, either it is formulated in various international treaties related to investment or practiced in customary international law. The NPM clause is very important to be included in the new Indonesian BIT Model based on some considerations. The NPM clause may transfer risk from the state to foreign investors in extraordinary situations and the it can limit investor protection in certain situations that are needed by the state to maintain and to protect public orders, national security, and other essential security interests. On the other hand,

65 This flexibility is very important to prevent lawsuits in arbitration forums as in the case of White Industries Australia Limited v. Republic of India, Philip Morris Asia Ltd. v. Australia, Lone Pine Resources Inc. v. The Government of Canada, where the host states are sued by investors for their policies that are important for the public interest. See Michael Nolan, "Challenge to the Credibility of the Investor state arbitration system", 2015, p. 430; Matthew C. Porterfield, "Exhaustion of Local Remedies in Investor State Dispute Settlement: AN Idea Whose Time has Come", 2015, p. 11; Sefriani, "Grounding and Utilizing International Law: the BIT model for Indonesia", Inaugural Speech of the Professor of Law before the Indonesian Islamic University in the field of international law, , January 12, 2019.

66 The Freeport Indonesia work contract, for example, is 30 years and can be extended for the same period.

67 William W. Burke-White and Andreas von Staden, op.cit., pp. 389-400. 
the NPM clause also provides greater flexibility to Indonesia as the host state to set its investment policies to achieve sustainable development to realize the welfare of the people, protect labor rights, public health, safety, the environment, public morals, and public order. The NPM clause is needed during the recovery stage after an international financial crisis occurs. It can also balance the protection of investors with the protection of Indonesia as the host state.

\section{Reference}

\section{Books}

I.B.R. Supancana, Kompendium Bidang Hukum Investasi, 2011, BPHN, Jakarta.

Rahmi Jened, Teori dan Kebijakan Investasi langsung (Direct Investment), $1^{\text {st }}$ Edition, Kencana, Jakarta, 2016.

Salim, HS, Hukum Divestasi di Indonesia, Erlangga, Jakarta, 2010.

UNCTAD, World Investment Report 2015: reforming international Investment Governance, United Nations Publication, Geneva, 2015.

\section{Other Documents}

Arman Nefi, et.al., "Implikasi Keberlakuan Kontrak Karya Pt Freeport Indonesia Pasca Undang-Undang No 4 Tahun 2009 Tentang Pertambangan Mineral dan Batubara", Jurnal Hukum dan Pembangunan, Volume 48, Issue 1, 2018.

Badan Koordinasi Penanaman Modal, "Review P4M Indonesia-Negara Mitra", Paper presented in Invest Remarkable in Indonesia, Jakarta, May 2015.

Burke-White, et.al., "Investment Protection in Extraordinary Times: The Interpretation And Application Of Non-Precluded Measures Provisions In Bilateral Investment Treaties, Virginia Journal of International Law, Volume 48, Issue 2, 2008.

Contesa, Maria, et.al., "Smelter: Inkonsistensi Kebijakan, Kendala dan Dampak di Indonesia", Responsive, Volume 1, No. 1, 2018.

Fry, James D and Odysseas G. Repousis, "Towards a new World for Investor -State Arbitration Through Transparancy", New York University Journal of International Law and Politics, Volume 48, No. 3, 2016.

Godoy, Federico, "State of Necessity and Non-Precluded Measures - Implications of the Sempra and Enron Annulment Decisions", IBA Arab News, Issue 1, 2011.

Goodman, Charity L., "Uncharted Waters: Financial Crisis and Enforcement Of ICSID Awards In Argentina", University of Pennsylvania Journal of International Law, Volume 28, Issue 2, 2007.

Hikmahanto, J., "Indonesia Should Withdraw from the ICSID!", The Jakarta Post, April, https://www.thejakartapost.com/news/2014/04/02/indonesia-shouldwithdraw-icsid.html, accessed on June 2019. 
Ikenberry, G. John and Anne-Marie Slaughter, "Forging a World of Liberty Under Law: U.S. National Security in the 21st Century", this paper is presented during the Princeton Project on National Security, September 2016.

Indonesia for Global Justice, "Catatan dari Sengketa Investasi \& Perdagangan Internasional", $\quad$ http://igj.or.id/wp-content/uploads/2017/01/Akhir-darisengketa-Perjanjian-Internasional.pdf, accessed on June 2019.

Ismailov, Otabek, "Interaction Of International Investment And Trade Regimes On Interpreting Treaty "Necessity" Clauses: Convergence Or Divergence?", Georgetown Journal of International Law, Volume 48, 2017.

Kim, Julie, "Balancing Regulatory Interests Through An Exceptions Framework Under The Right To Regulate Provision In International Investment Agreements", George Washington International Law Review, Volume 50, No. 2, 2018.

Korzun, Vera, "The Right To Regulate In Investor-State Arbitration: Slicing And Dicing Regulatory Carve-Outs", Vanderbilt Journal of Transnational Law, Volume 50, 2018.

Moloo, Rahim \&Justin Jacinto, "Environmental and Health Regulation: Assessing Liability Under Investment Treaties", Berkeley Journal of International Law, Volume 29, Issue 1, 2011.

Nam, Jeongho ," Model BIT: An Ideal Prototype Or A Tool For Efficient Breach, Georgetown Journal of International Law, Volume 48, 2017.

Nolan, Michael, "Challenge to the Credibility of the Investor state arbitration system", American University Business Law Review, Volume 5, Issue, 2015.

Olmedo, Javier Garcia, The Balance between NPM Clauses and Investors Protection under BITs: The Enron Annulment Decision, IBA Arab News, issue 1, 2011.

Patel, Nikesh, "An Emerging Trend in International Trade: A shift to safeguard against ISDS abuses and protect host state sovereignty", Minnesota Journal of International Law, Volume 26, 2017.

Porterfield, Matthew C., "Exhaustion of Local Remedies in Investor State Dispute Settlement: AN Idea Whose Time has Come", Yale Journal of International Law, Volume 41, Issue 1, 2015.

Riyatno, "Investment Dispute and International Arbitration", paper presented in BANI, November 2017.

Sefriani, "Fair and Equitable Treatment Standard in International Investment Agreements", Jurnal Yustisia, Volume 7, Issue 1, 2018.

Sefriani, "Membumikan dan Memanfaatkan Hukum Internasional: model BIT untuk Indonesia", Speech delivered on inauguration of Professor on behalf Dr. Sefriani, S.H., M.H. in Universitas Islam Indonesia. 


\section{Legal Documents}

Agreement for the Promotion and Protection of Investments between India and Netherlands, November 1995, http://www.iisd.org/pdf/2006/investment india netherlands.pdf, accessed on June 2019.

Canadian Model Foreign Investment Protection and Promotion Agreement (FIPA), 2004, http://www.dfait-maeci.gc.ca/tna-nac/documents/2004-FIPA-modelen.pdf, accessed on June 2019. 